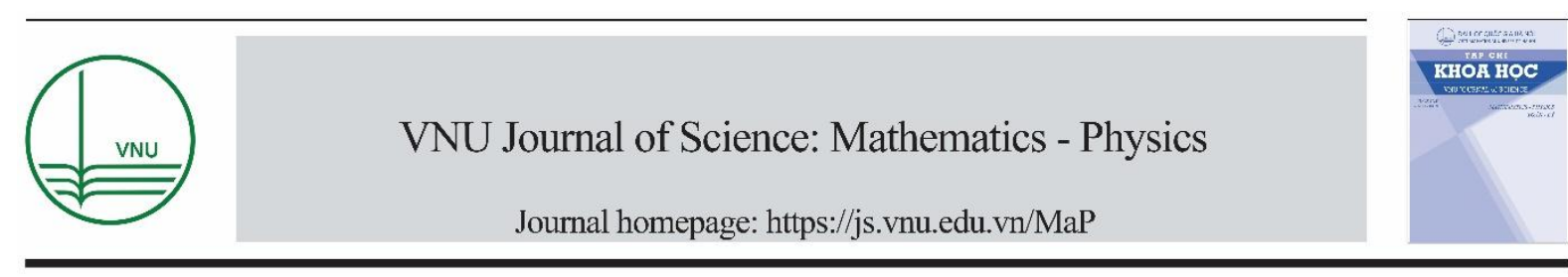

Original Article

\title{
Structure Analysis of Amorphous and Liquid Magnesium Silicate
}

\author{
Mai Thi Lan ${ }^{1, *}$, Nguyen Thi Thao ${ }^{2}$ \\ ${ }^{1}$ Hanoi University of Science and Technology, 1 Dai Co Viet, Hai Ba Trung, Hanoi, Vietnam \\ ${ }^{2}$ Hong Duc University, 565 Quang Trung, Dong Ve, Thanh Hoa, Vietnam
}

Received 05 May 2020

Revised 19 May 2020; Accepted 15 June 2020

\begin{abstract}
We use the Oganov potentials and period boundary condition to perform molecular dynamics simulation of amorphous and liquid $\mathrm{Mg} 2 \mathrm{SiO} 4$ systems under pressures $0 \mathrm{GPa}$ and $40 \mathrm{GPa}$. We clarify structure of amorphous $\mathrm{Mg} 2 \mathrm{SiO} 4$ at 0 and $40 \mathrm{GPa}$ and compared with the one of $\mathrm{Mg} 2 \mathrm{SiO} 4$ at liquid state. Especially, the origin of sub-peaks in radial distribution function of O-O, Si-Si and $\mathrm{Mg}-\mathrm{Mg}$ pairs is explained clearly. The change of radial distribution functions, coordination number and the number of all types of bonds including the corner-, edge- and face-sharing bonds is also discussed in detail in this paper. Keywords: Molecular dynamics simulation, magnesium silicate, structure.
\end{abstract}

\section{Introduction}

Magnesium silicate $\left(\mathrm{Mg}_{2} \mathrm{SiO}_{4}\right)$ is one of the most abundant materials of the Earth's upper mantle $[1,2]$. It is also an important component in many high technology applications [3]. $\mathrm{Mg}_{2} \mathrm{SiO}_{4}$ system has been extensively investigated for a long time by both experiment (X-ray diffraction, nuclear magnetic resonance, Raman spectroscopy technology) [4-6] and simulation (Molecular Dynamics, Monte Carlo) [1-3, 7-11]. Knowledge of structure of $\mathrm{Mg}_{2} \mathrm{SiO}_{4}$ system in both solid and liquid states at different temperature and pressure conditions is necessary for understanding about thermal change of the Earth as well as application in the process of new material fabrication technology. The X-ray diffraction and Neutron scattering experimental results showed that [8] $\mathrm{Si}$ atoms in $\mathrm{Mg}_{2} \mathrm{SiO}_{4}$ glass has mainly 4 coordinated oxygens and the mean bond length of $\mathrm{Si}-\mathrm{O}$ is about $1.60 \AA$. Meanwhile the $\mathrm{Mg}$ atoms are surrounded 5 oxygens and the $\mathrm{Mg}-\mathrm{O}$ bond length is about $2.0 \AA$. Using nuclear magnetic resonance $[4$,

\footnotetext{
${ }^{*}$ Corresponding author.

Email address: lan.maithi@ hust.edu.vn
}

https//doi.org/ 10.25073/2588-1124/vnumap.4520 
5] authors indicated that the coordination number of $\mathrm{Mg}$ is 5 and 6 . The simulation results $[2,10,11]$ also showed that structure $\mathrm{Mg}_{2} \mathrm{SiO}_{4}$ comprise basic structural unit $\mathrm{TO}_{\mathrm{n}}(\mathrm{T}=\mathrm{Si}, \mathrm{Mg} ; n$ is the number of oxygens that surrounded $\mathrm{T}$ atoms). There is change of the coordination number of $\mathrm{Si}$ and $\mathrm{Mg}$ atoms and intermediate range order structure in magnesium silicate melts under compression [2]. Molecular dynamics simulation of $\mathrm{MgSiO}_{3}$ liquid $[12,13]$ clarified structural organization, network topology as well as the degree of polymerization under compression. In this work, we clarify structure of amorphous $\mathrm{Mg}_{2} \mathrm{SiO}_{4}$ at 0 and $40 \mathrm{GPa}$ and compared with the one of liquid $\mathrm{Mg}_{2} \mathrm{SiO}_{4}$. Especially, the origin of subpeaks in radial distribution function of $\mathrm{O}-\mathrm{O}, \mathrm{Si}-\mathrm{Si}$ and $\mathrm{Mg}-\mathrm{Mg}$ pairs also explain via analysis the $\mathrm{TO}_{\mathrm{n}}$ units as well as the corner-, edge- and face-sharing bonds between adjacent structural units $\mathrm{TO}_{\mathrm{n}}$.

\section{Calculation Method}

Molecular dynamics simulations are used to construct $\mathrm{Mg}_{2} \mathrm{SiO}_{4}$ models containing several thousand atoms. Simulation method is recognized as a numerical empirical method and plays a close link between
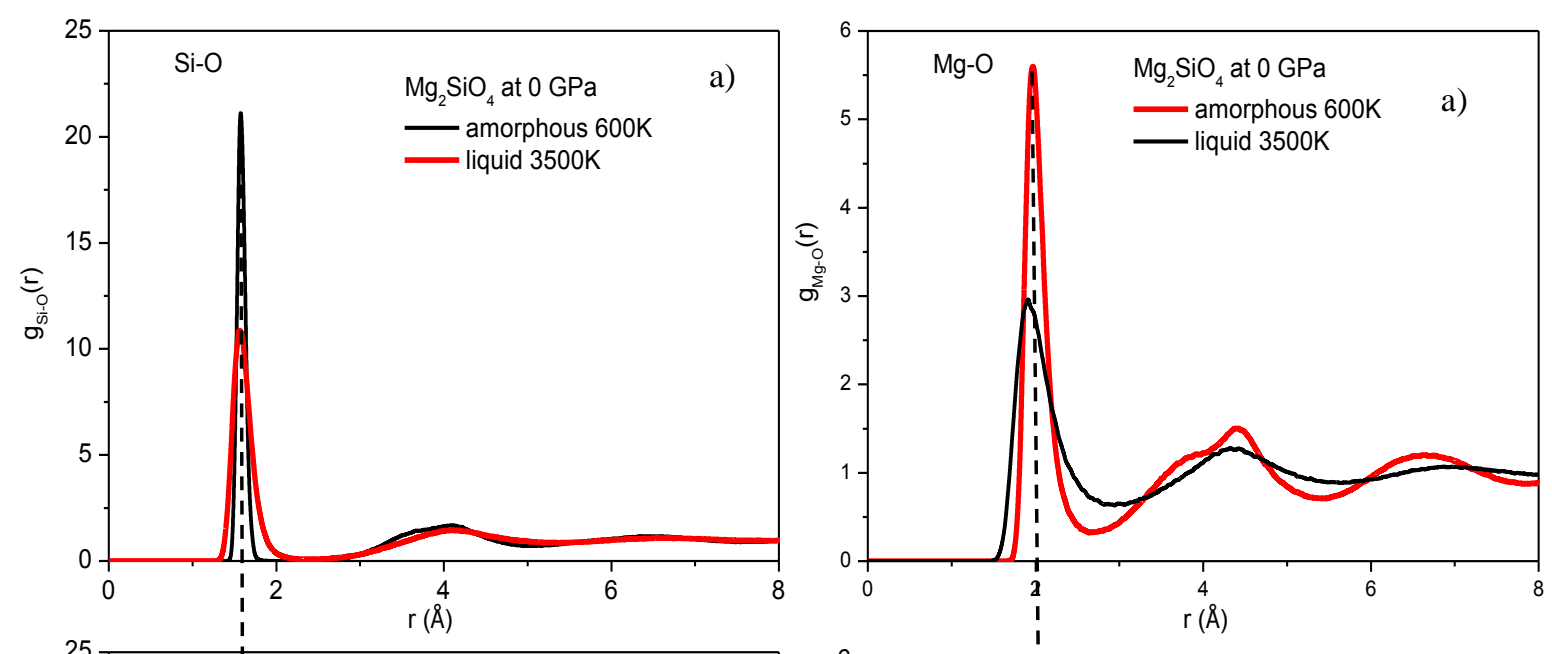

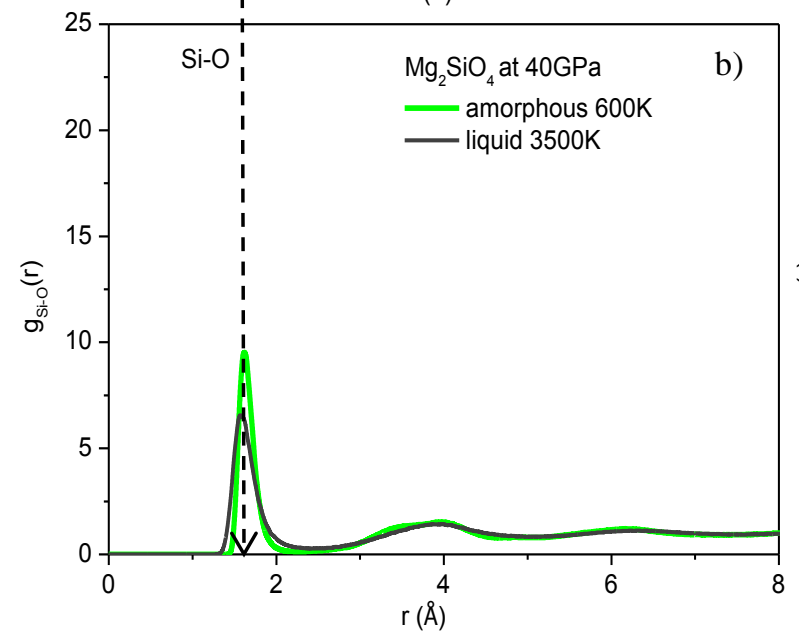

Figure 1. The radial distribution function of $\mathrm{Si}-\mathrm{O}$ pair at both states at $0 \mathrm{GPa}$ (a) and $40 \mathrm{GPa}(\mathrm{b})$

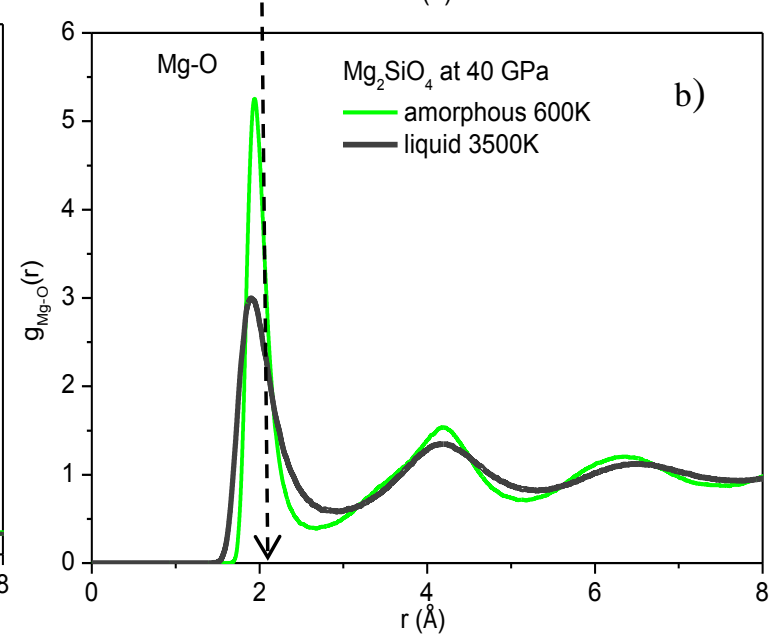

Figure 2. The radial distribution function of $\mathrm{Mg}-\mathrm{O}$ pair at both states and at $0 \mathrm{GPa}$ (a) and $40 \mathrm{GPa}(\mathrm{b})$ 
two theoretical and empirical methods. The initial configuration of the sample is built by randomly placing $4998 \mathrm{Si}, \mathrm{Mg}$ and $\mathrm{O}$ atoms in a simulation box with the condition that no two atoms are too close together. The motion of atoms in the model follows the Newton's equation of motion. We used the Verlet algorithm to integrate the equation of motion, the Ewald-Hansen approximation technique applied to significantly reduce the time taken to calculate the Coulomb interaction at a distance. The Oganov potentials are used to construct $\mathrm{Mg}_{2} \mathrm{SiO}_{4}$ models $[11,12]$. Under the influence of the interaction force, the atoms will shift to the equilibrium position. The equilibrium state of the model is determined when the energy of the model is stable. Hence, the structural characteristics and properties of the models are determined. Detail about the process of constructing models of magnesium silicate system can be refer in our recent studies [12]
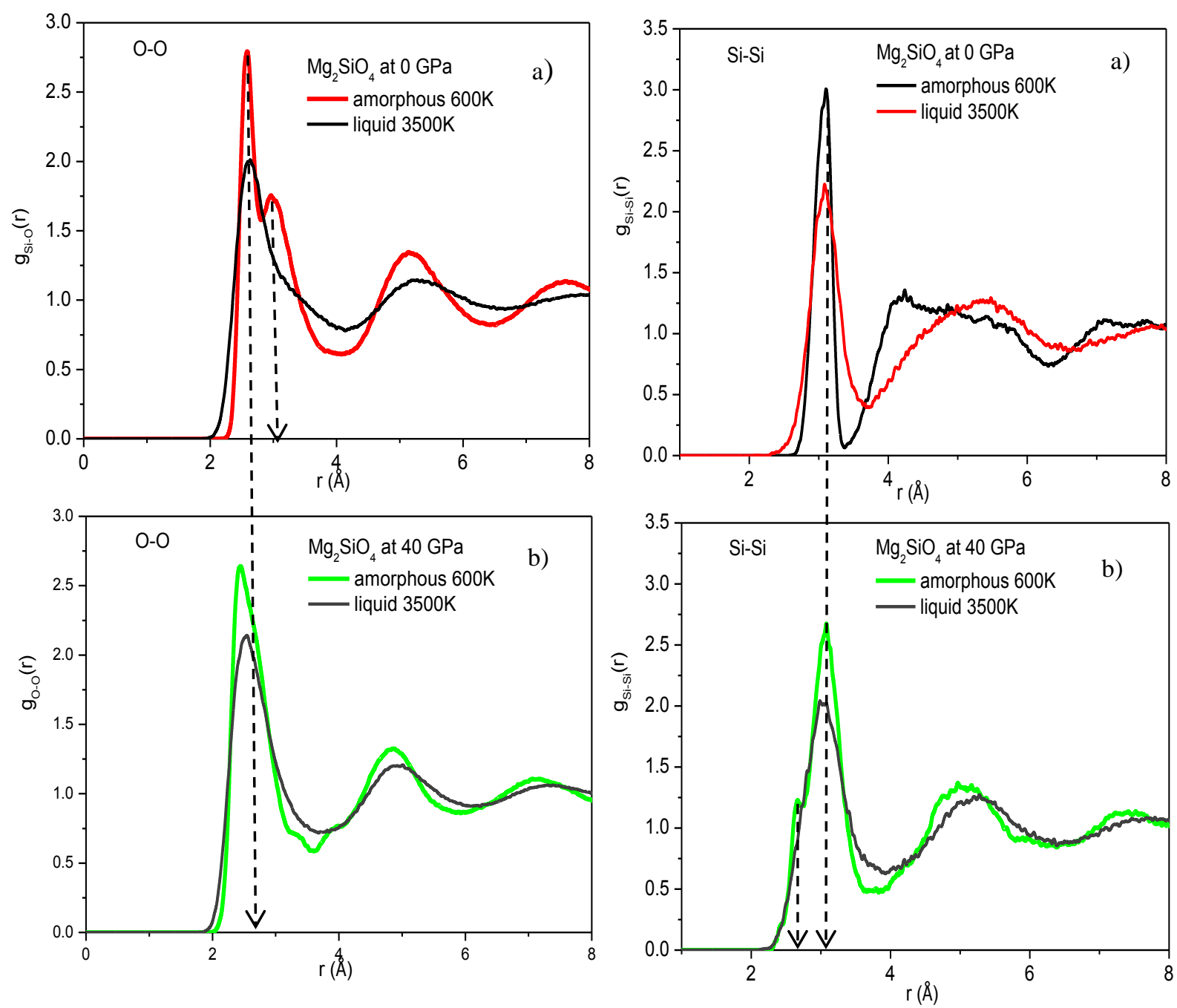

Figure 3. The radial distribution function of $\mathrm{O}-\mathrm{O}$ pair at both states at $0 \mathrm{GPa}$ (a) and $40 \mathrm{GPa}$ (b).

Figure 4. The radial distribution function of $\mathrm{Si}-\mathrm{Si}$ pair at both states at $0 \mathrm{GPa}$ (a) and $40 \mathrm{GPa}$ (b). 


\section{Results and Discussion}

First, we calculate radial distribution function of T-O, O-O and T-T pairs at both states and at $0 \mathrm{GPa}$ and $40 \mathrm{GPa}$. Regarding to Si-O pair, figure 1a shows that at $0 \mathrm{GPa}$, the position of the first peak at amorphous and liquid states is about $1.62 \AA$. It means that $\mathrm{Si}-\mathrm{O}$ bond length is almost not dependent on temperature. At $40 \mathrm{GPa}$, the position of the first peak at liquid state tends to shift slightly to the left

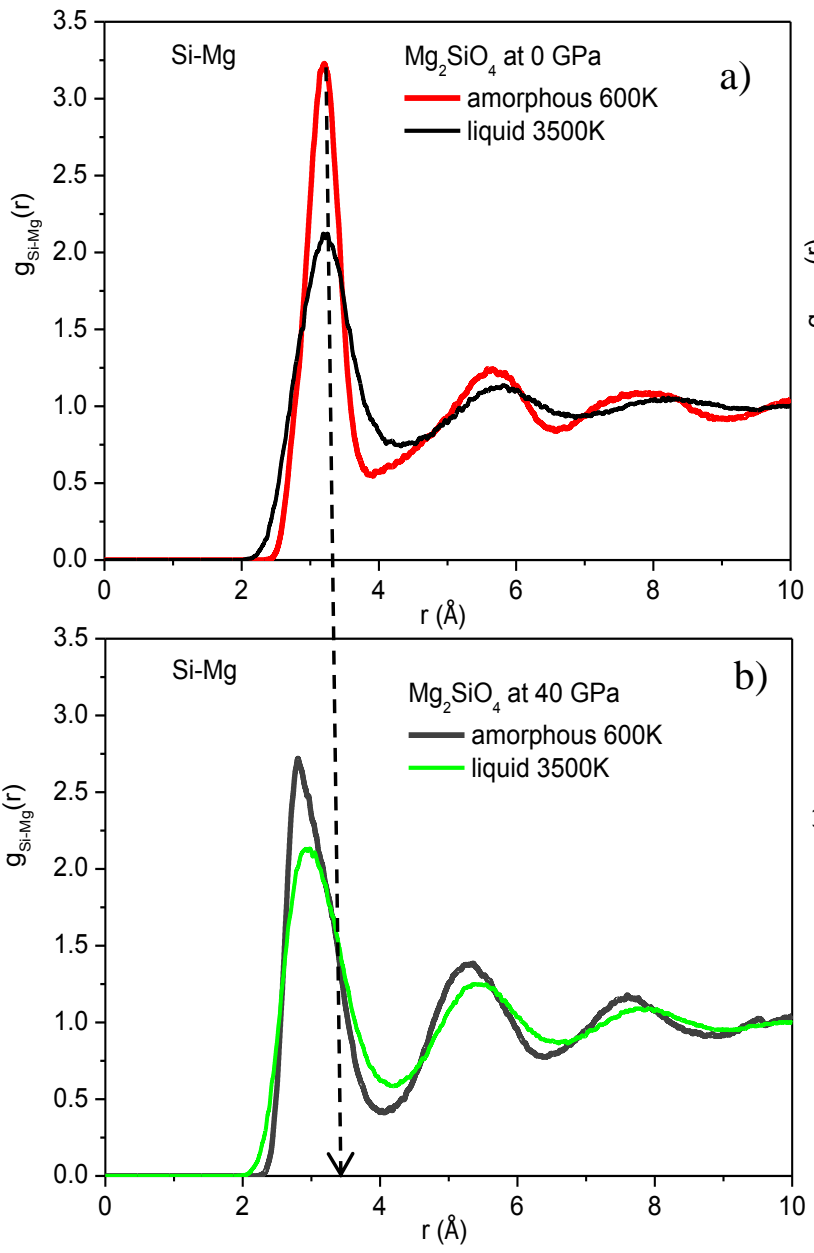

Figure 5. The radial distribution function of $\mathrm{Si}-\mathrm{Mg}$ pair at both states at $0 \mathrm{GPa}$ (a) and $40 \mathrm{GPa}(\mathrm{b})$.

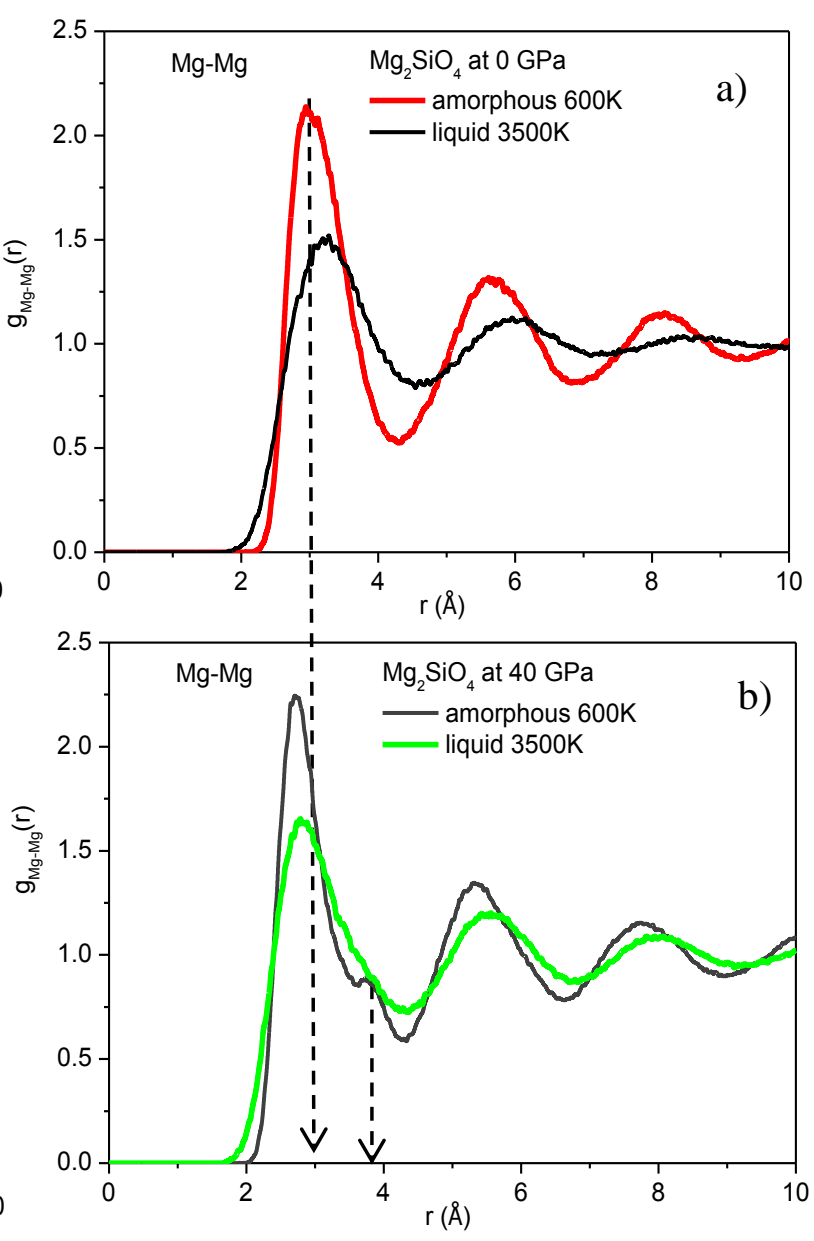

Figure 6. The radial distribution function of $\mathrm{Mg}-\mathrm{Mg}$ pair at both states at $0 \mathrm{GPa}(\mathrm{a})$ and $40 \mathrm{GPa}(\mathrm{b})$.

compare to the one at amorphous state and at $0 \mathrm{GPa}$. The $\mathrm{Si}-\mathrm{O}$ bond length at $40 \mathrm{GPa}$ is smaller than the one at $0 \mathrm{GPa}$ (see figure $1 \mathrm{~b}$ ). Besides at the same pressure, the height of the first peak in liquid state is smaller than the one in amorphous states. The full width at half maximum of the first peak in liquid state is larger than the one in amorphous states. It means that the degree of structural order in $\mathrm{Mg}_{2} \mathrm{SiO}_{4}$ at amorphous is higher than the one in liquid state. The degree of structural order in $\mathrm{Mg}_{2} \mathrm{SiO}_{4}$ at $40 \mathrm{GPa}$ is higher than the one at $0 \mathrm{GPa}$. Regarding to $\mathrm{Mg}-\mathrm{O}$, figure $2 \mathrm{a}$ indicates that the $\mathrm{Mg}$-O bond length in amorphous is about $1.94 \AA$ and the Mg-O bond length is longer than the one in liquid state. Under compression, the first peaks in both states shift to the left, it means that the Mg-O length decreases as pressure increases. For $\mathrm{O}-\mathrm{O}$ pair, it can be seen that there are two peaks in the $\mathrm{O}-\mathrm{O}$ radial distribution 
function in amorphous state at $0 \mathrm{GPa}$ (see figure 3a). This is not appearance in amorphous state at 40 $\mathrm{GPa}$ and in liquid state at 0 and $40 \mathrm{GPa}$ (see figure $3 \mathrm{a}, \mathrm{b}$ ). The main peak is about $2.6 \AA$ and the subpeak is about $3.02 \AA$. The position of the first peak of O-O pair shifts to left, thus the O-O bond length decreases when pressure increases from 0 to $40 \mathrm{GPa}$. Figure 4 indicates the $\mathrm{Si}$-Si radial distribution function at both states. The results show that at $0 \mathrm{GPa}$ and in both states, it has the first peak at location of about $3.10 \AA$ A However, at $40 \mathrm{GPa}$, the Si-Si radial distribution function in amorphous state appears a shoulder at around 2.82 A. For Si-Mg pair (see figure 5), the Si-Mg bond distance decreases strongly at both states as pressure increases. At $0 \mathrm{GPa}$, the $\mathrm{Si}-\mathrm{Mg}$ bond distance in amorphous and liquid states is about $3.20 \AA$ and $3.40 \AA$ at $0 \mathrm{GPa}$, respectively. At $40 \mathrm{GPa}$, these bond distances in amorphous and liquid states is about $2.80 \AA$ and $2.60 \AA$, respectively. In the $\mathrm{Mg}-\mathrm{Mg}$ pair radial distribution function, it appears a shoulder at location of $3.80 \AA$ in amorphous state at $40 \mathrm{GPa}$. Meanwhile, the radial distribution function of $\mathrm{Mg}-\mathrm{Mg}$ pair in both states at $0 \mathrm{GPa}$ and in liquid state at $40 \mathrm{GPa}$ has only the main first peak at around $2.8-3.2 \AA$. The $\mathrm{Mg}-\mathrm{Mg}$ bond distances at $0 \mathrm{GPa}$ are larger than the one at $40 \mathrm{GPa}$. Next, we calculate distribution of the coordination number for simulated $\mathrm{Mg}_{2} \mathrm{SiO}_{4}$ system at both states and at 0 and $40 \mathrm{GPa}$, it showed on table 1 .

Table 1. Distribution of the coordination number for simulated $\mathrm{Mg}_{2} \mathrm{SiO}_{4}$ system at both states and at 0 and 40 $\mathrm{GPa} ; \mathrm{C}_{\mathrm{x}}$ are the fraction of $\mathrm{SiO}_{\mathrm{x}}$ units $(\mathrm{x}=4-6), \mathrm{D}_{\mathrm{y}}$ are the fraction of $\mathrm{MgO}_{\mathrm{y}}$ units $(\mathrm{y}=3-8)$

\begin{tabular}{|c|c|c|c|c|}
\hline \multirow{2}{*}{$\begin{array}{c}\text { Fraction } \\
(\%)\end{array}$} & \multicolumn{2}{|c|}{ amorphous state } & \multicolumn{2}{c|}{ liquid state } \\
\cline { 2 - 5 } & $0 \mathrm{GPa}$ & $40 \mathrm{GPa}$ & $0 \mathrm{GPa}$ & $40 \mathrm{GPa}$ \\
\hline $\mathrm{C}_{4}$ & 92.20 & 9.90 & 99.20 & 10.79 \\
\hline $\mathrm{C}_{5}$ & 5.60 & 46.90 & 0.80 & 46.61 \\
\hline $\mathrm{C}_{6}$ & 0.10 & 42.30 & 0.00 & 42.59 \\
\hline $\mathrm{D}_{3}$ & 14.20 & 0.00 & 0.45 & 0.00 \\
\hline $\mathrm{D}_{4}$ & 39.90 & 0.10 & 32.67 & 0.01 \\
\hline $\mathrm{D}_{5}$ & 32.90 & 3.50 & 49.58 & 2.53 \\
\hline $\mathrm{D}_{6}$ & 10.40 & 24.70 & 16.87 & 39.37 \\
\hline $\mathrm{D}_{7}$ & 1.20 & 41.50 & 0.43 & 42.40 \\
\hline $\mathrm{D}_{8}$ & 0.10 & 24.30 & 0.00 & 15.69 \\
\hline
\end{tabular}

The results show that, at amorphous state there are percentage of $\mathrm{SiO} 4$ units is $92.20 \%$ at $0 \mathrm{GPa}$. At $40 \mathrm{GPa}$, the fraction of $\mathrm{SiO}_{4}$ decreases strongly while the fraction of $\mathrm{SiO}_{5}$ and $\mathrm{SiO}_{6}$ increase sharply. It means that there is structural phase transition from $\mathrm{SiO}_{4}$ to $\mathrm{SiO}_{5}$ and $\mathrm{SiO}_{6}$ units under compression. The fraction of $\mathrm{SiO}_{\mathrm{x}}$ units in $\mathrm{Mg}_{2} \mathrm{SiO}_{4}$ in liquid states is similar to the one in amorphous states and at both pressure 0 and $40 \mathrm{GPa}$. Relating to $\mathrm{MgOy}$ units, it can be seen that there is difference about the percentage of structural units $\mathrm{MgOy}$ at amorphous and liquid states as well as at different pressure. Namely, at $0 \mathrm{GPa}$, the fraction of $\mathrm{MgO}_{3}, \mathrm{MgO}_{4}$ and $\mathrm{MgO}_{5}$ units is dominant in amorphous $\mathrm{Mg}_{2} \mathrm{SiO}_{4}$, meanwhile the fraction of $\mathrm{MgO}_{4}, \mathrm{MgO}_{5}$ and $\mathrm{MgO}_{6}$ units is dominant in liquid $\mathrm{Mg}_{2} \mathrm{SiO}_{4}$. At $40 \mathrm{GPa}$, percentage of $\mathrm{MgO}_{6}, \mathrm{MgO}_{7}$ and $\mathrm{MgO}_{8}$ is dominant in both states. The above analysis illustrates that the structure of amorphous $\mathrm{Mg}_{2} \mathrm{SiO}_{4}$ is built mainly by the $\mathrm{SiO}_{4}, \mathrm{MgO}_{3}, \mathrm{MgO}_{4}$ and $\mathrm{MgO}_{5}$ and a number of small $\mathrm{SiO}_{5}$ network at $0 \mathrm{GPa}$. Meanwhile, the structure of liquid $\mathrm{Mg}_{2} \mathrm{SiO}_{4}$ is built mainly by the $\mathrm{SiO}_{4}$, 
$\mathrm{MgO}_{4}, \mathrm{MgO}_{5}$ and $\mathrm{MgO}_{6}$ network. At $40 \mathrm{GPa}$, the network structure of $\mathrm{Mg}_{2} \mathrm{SiO}_{4}$ at both states consists of $\mathrm{SiO}_{5}, \mathrm{SiO}_{6}, \mathrm{MgO}_{6}, \mathrm{MgO}_{7}$ and $\mathrm{MgO}_{8}$ network. These $\mathrm{SiO}_{\mathrm{x}}, \mathrm{MgO}_{\mathrm{y}}$ structural units can be link to each other via oxygens to form network structure of $\mathrm{Mg}_{2} \mathrm{SiO}_{4}$ system that visualized in figure 7 and 8 .
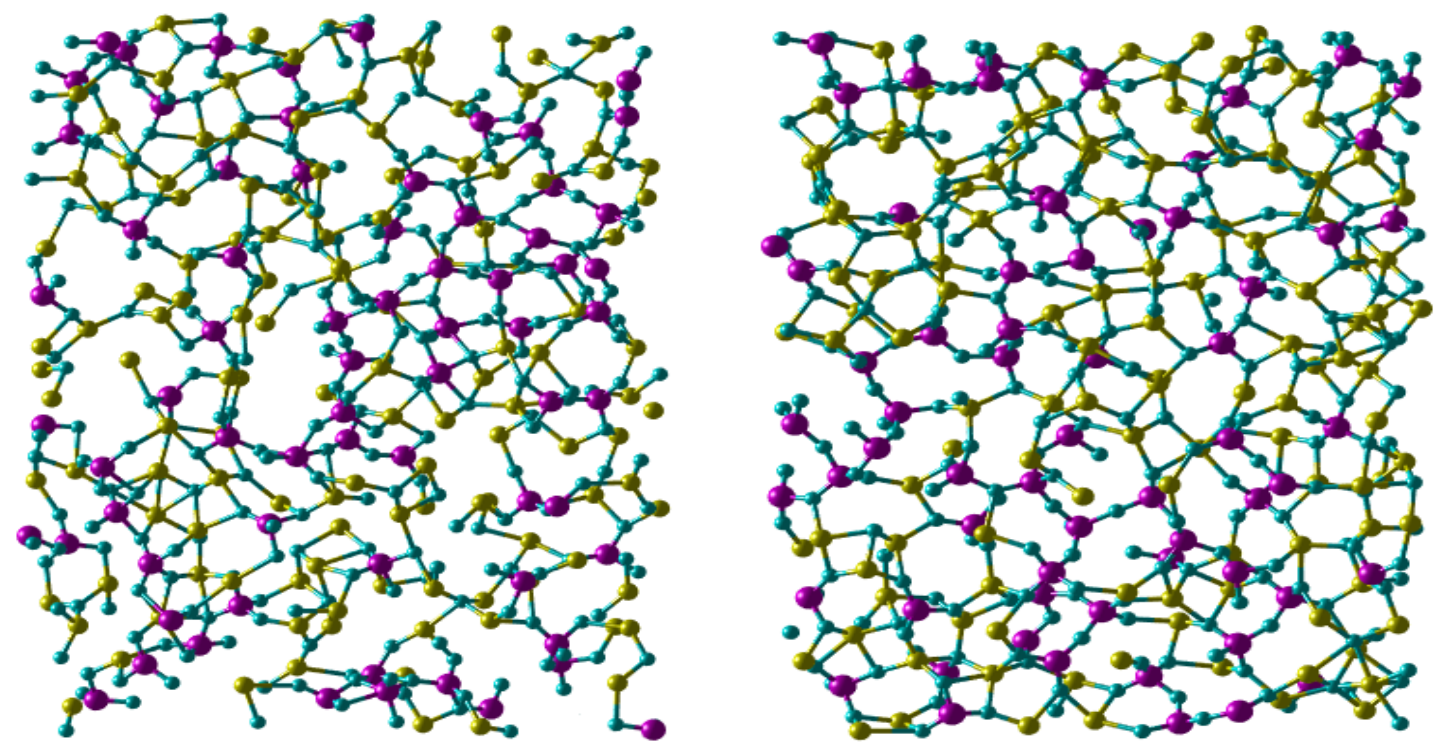

Figure 7. The snapshot of network structure of $\mathrm{Mg}_{2} \mathrm{SiO}_{4}$ at $0 \mathrm{GPa}$ and at both states: amorphous (left) and liquid (right)
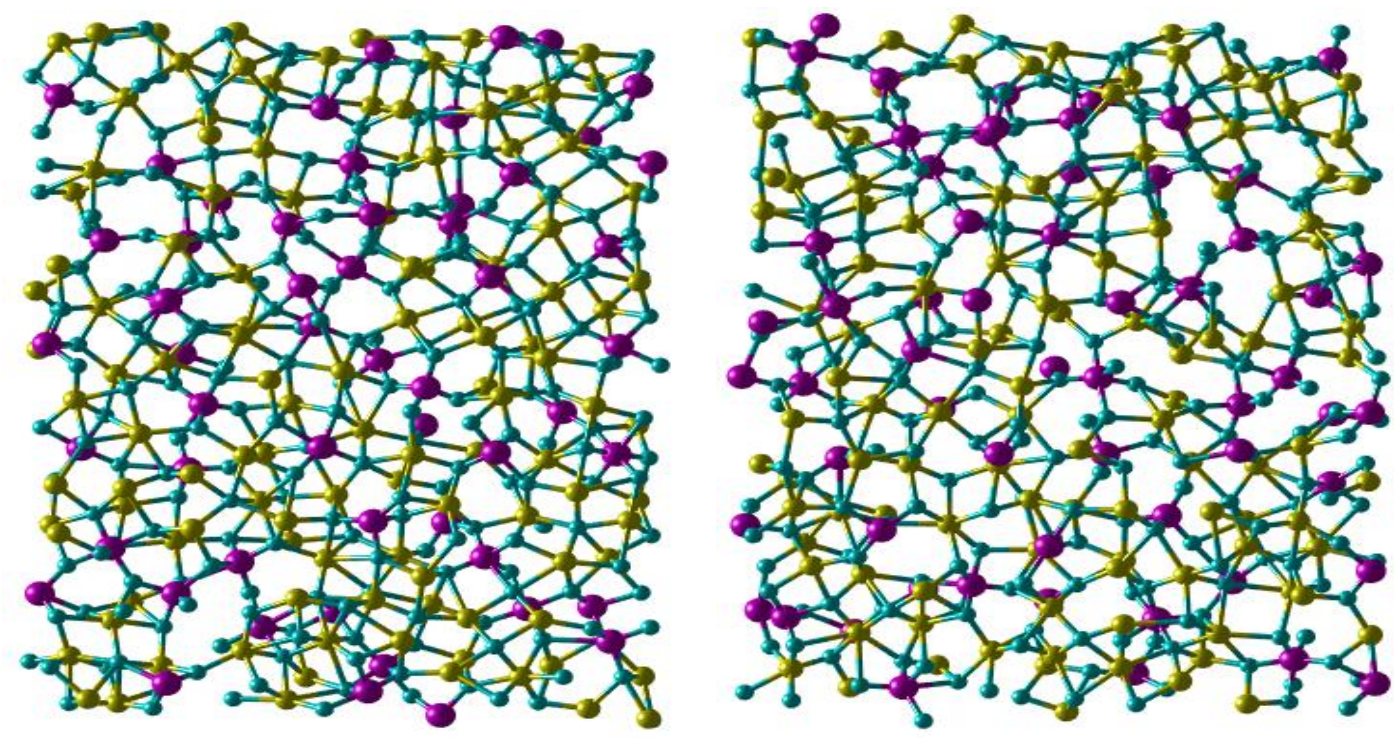

Figure 8. The snapshot of network structure of $\mathrm{Mg}_{2} \mathrm{SiO}_{4}$ at $40 \mathrm{GPa}$ and at both states: amorphous (left) and liquid (right).

It can be seen that the atoms tend to arrange more orderly at $40 \mathrm{GPa}$ compare to $0 \mathrm{GPa}$. The O-O bond distance depends on the $\mathrm{O}-\mathrm{Si}-\mathrm{O}$ and $\mathrm{O}-\mathrm{Mg}-\mathrm{O}$ bond angle in the $\mathrm{SiO}_{\mathrm{x}}$ and $\mathrm{MgO}_{\mathrm{y}}$ units, respectively. 
The previous studies $[2,13,14]$ indicated that magnesium silicate system at $0 \mathrm{GPa}$ has the $\mathrm{O}-\mathrm{Si}-\mathrm{O}$ and $\mathrm{O}-\mathrm{Mg}-\mathrm{O}$ bond angle are different, around $105-110^{\circ}$ and $85-90^{\circ}$ degree, respectively. Meanwhile, at high pressure (40GPa) or in liquid $\mathrm{Mg}_{2} \mathrm{SiO}_{4}$, the $\mathrm{O}-\mathrm{Si}-\mathrm{O}$ and $\mathrm{O}-\mathrm{Mg}-\mathrm{O}$ bond angle are almost the same. Thus, there are only two O-O bond distances in amorphous $\mathrm{Mg}_{2} \mathrm{SiO}_{4}$ at $0 \mathrm{GPa}$. This leads to existence of subpeak in the $\mathrm{O}-\mathrm{O}$ radial distribution function in amorphous $\mathrm{Mg}_{2} \mathrm{SiO}_{4}$ at $0 \mathrm{GPa}$. Furthermore, in amorphous $\mathrm{Mg}_{2} \mathrm{SiO}_{4}$ at $40 \mathrm{GPa}, \mathrm{MgO}_{\mathrm{y}}$ are mainly $\mathrm{MgO}_{6}, \mathrm{MgO}_{7}$ and $\mathrm{MgO}_{8}$ units. The $\mathrm{Mg}-\mathrm{O}-\mathrm{Mg}$ bond angle distribution has a peak at around 80 and a shoulder at around 150 degree [14]. This is original of appearance of sub-peak in the $\mathrm{Mg}-\mathrm{Mg}$ pair radial distribution function in amorphous $\mathrm{Mg}_{2} \mathrm{SiO}_{4}$ at 40 $\mathrm{GPa}$. We continue studying all type of links between adjacent $\mathrm{SiO}_{\mathrm{x}}$ units, adjacent $\mathrm{MgOy}$ units and adjacent $\mathrm{SiO}_{\mathrm{x}}$ and $\mathrm{MgO}_{\mathrm{y}}$ units in $\mathrm{Mg}_{2} \mathrm{SiO}_{4}$ system. We found that there are three type of links including the corner-, edge- and face-sharing bonds. The number of the corner-, edge- and face-sharing bonds is showed in Table 2.

Table 2. The number of corner-, edge- and face-sharing bonds (denoted $\mathrm{N}_{\text {corner }}, \mathrm{N}_{\text {edge }}$ and $\mathrm{N}_{\text {face }}$ respectively) between adjacent $\mathrm{TO}_{\mathrm{n}}$ units $(\mathrm{T}=\mathrm{Si}, \mathrm{Mg})$

\begin{tabular}{|l|c|c|c|c|c|}
\hline \multirow{2}{*}{ Structural units } & & \multicolumn{2}{|c|}{ amorphous state } & \multicolumn{2}{c|}{ liquid state } \\
\cline { 2 - 6 } & & $0 \mathrm{GPa}$ & $40 \mathrm{GPa}$ & $0 \mathrm{GPa}$ & $40 \mathrm{GPa}$ \\
\hline \multirow{2}{*}{$\mathrm{SiO}_{\mathrm{x}}-\mathrm{SiO}_{\mathrm{x}}$} & $\mathrm{N}_{\text {corner }}$ & 487 & 983 & 535 & 894 \\
\cline { 2 - 6 } & $\mathrm{N}_{\text {edge }}$ & 0 & 182 & 0 & 11 \\
\cline { 2 - 6 } & $\mathrm{N}_{\text {face }}$ & 0 & 29 & 0 & 46 \\
\hline \multirow{3}{*}{$\mathrm{MgO}_{\mathrm{y}}-\mathrm{MgO}_{\mathrm{y}}$} & $\mathrm{N}_{\text {corner }}$ & 3574 & 4483 & 3222 & 4609 \\
\cline { 2 - 6 } & $\mathrm{N}_{\text {edge }}$ & 1746 & 2651 & 1052 & 2511 \\
\cline { 2 - 6 } & $\mathrm{N}_{\text {face }}$ & 267 & 1407 & 152 & 1232 \\
\hline \multirow{2}{*}{$\mathrm{SiO}_{\mathrm{x}}-\mathrm{MgO}_{\mathrm{y}}$} & $\mathrm{N}_{\text {corner }}$ & 4077 & 3980 & 2857 & 4080 \\
\cline { 2 - 6 } & $\mathrm{N}_{\text {edge }}$ & 367 & 2402 & 460 & 2014 \\
\cline { 2 - 6 } & $\mathrm{N}_{\text {face }}$ & 2 & 488 & 15 & 463 \\
\hline
\end{tabular}

It can be seen that at $0 \mathrm{GPa}$, links between two adjacent $\mathrm{SiO}_{\mathrm{x}}$ units are corner-sharing bonds in amorphous and liquid states. The number of corner-sharing bonds at amorphous and liquid state is 487 and 535, respectively. At $40 \mathrm{GPa}$, in both states, the adjacent $\mathrm{SiO}_{\mathrm{x}}$ units link each other by three types of bonds. The number of corner-sharing bonds is also dominant. Note that, the number of edge-sharing bonds in amorphous $\mathrm{Mg}_{2} \mathrm{SiO}_{4}$ at $40 \mathrm{GPa}$ is the largest. As above mentioned, the structure of amorphous $\mathrm{Mg}_{2} \mathrm{SiO}_{4}$ is mainly build by $\mathrm{SiO}_{4}$ units at $0 \mathrm{GPa}$ and $\mathrm{SiO}_{5}, \mathrm{SiO}_{6}$ units at $40 \mathrm{GPa}$. It means that links between two adjacent $\mathrm{SiO}_{4}$ units are corner-sharing bonds, meanwhile links between two adjacent $\mathrm{SiO}_{5}$, $\mathrm{SiO}_{6}$ units are corner-, edge-, and face- sharing. Thus, the appearance of sub-peak in Si-Si radial distribution function at around $2.82 \AA$ at $40 \mathrm{GPa}$ due to existence of the edge-, face-sharing bonds. For the adjacent $\mathrm{MgO}_{\mathrm{y}}$ units, they link to each other by all three types. At $0 \mathrm{GPa}$, the number of corner-, edge-, and face- sharing is 3574, 1746 and 267 in amorphous $\mathrm{Mg}_{2} \mathrm{SiO}_{4}$ and 3222, 1052 and 152 in liquid $\mathrm{Mg}_{2} \mathrm{SiO}_{4}$, respectively. As pressure increases, the number of all three types bonds increases. At $40 \mathrm{GPa}$, the number of corner-, edge-, and face- sharing is 4483, 2651 and 1407 in amorphous $\mathrm{Mg}_{2} \mathrm{SiO}_{4}$ and 4609, 2511 and 1232 in liquid $\mathrm{Mg} 2 \mathrm{SiO} 4$, respectively. Similar to the results for the adjacent $\mathrm{MgO}_{\mathrm{y}}$ units, the links between adjacent $\mathrm{SiO}_{\mathrm{x}}$ and $\mathrm{MgOy}$ units consist of all three types of bonds and the number of all three types bonds increases as increasing pressure. 


\section{Conclusion}

We find that the structure of $\mathrm{Mg}_{2} \mathrm{SiO}_{4}$ consists of basic structural units $\mathrm{TO}_{\mathrm{n}}(\mathrm{T}=\mathrm{Si}, \mathrm{Mg} ; \mathrm{n}=3-8)$. These $\mathrm{TO}_{\mathrm{n}}$ link to each other through oxygen atoms to form network structure. The T-O coordination number increases as pressure increases. The amorphous $\mathrm{Mg}_{2} \mathrm{SiO}_{4}$ comprises mainly $\mathrm{SiO}_{4}, \mathrm{MgO}_{3}, \mathrm{MgO}_{4}$ and $\mathrm{MgO}_{5}$ and a number of small $\mathrm{SiO}_{5}$ network at $0 \mathrm{GPa}$. Meanwhile, the structure of liquid $\mathrm{Mg}_{2} \mathrm{SiO}_{4}$ comprises $\mathrm{SiO}_{4}, \mathrm{MgO}_{4}, \mathrm{MgO}_{5}$ and $\mathrm{MgO}_{6}$ network. At $40 \mathrm{GPa}$, the network structure of $\mathrm{Mg}_{2} \mathrm{SiO}_{4}$ at both states consists of $\mathrm{SiO}_{5}, \mathrm{SiO}_{6}, \mathrm{MgO}_{6}, \mathrm{MgO}_{7}$ and $\mathrm{MgO}_{8}$ network. In amorphous and liquid $\mathrm{Mg} 2 \mathrm{SiO} 4$ system, the links between the adjacent $\mathrm{SiO}_{\mathrm{x}}$ units are mainly corner- and edge-sharing bonds. Meanwhile the links between the adjacent $\mathrm{MgO}_{\mathrm{y}}$ units, the adjacent $\mathrm{SiO}_{\mathrm{x}}$ and $\mathrm{MgOy}$ units are all types of bonds including corner-, edge-, and face- sharing bonds. The appearance of the sub-peaks in radial distribution function of $\mathrm{Si}-\mathrm{Si}$ pair due to existence of the number of significantly edge- and face-sharing bonds in amorphous $\mathrm{Mg}_{2} \mathrm{SiO}_{4}$ at $40 \mathrm{GPa}$. The existence of the sub-peak in the $\mathrm{O}-\mathrm{O}$ radial distribution function in amorphous $\mathrm{Mg}_{2} \mathrm{SiO}_{4}$ at $0 \mathrm{GPa}$ is due to difference of the $\mathrm{O}-\mathrm{Si}-\mathrm{O}$ and $\mathrm{O}-\mathrm{Mg}-\mathrm{O}$ bond angle. The original the sub-peak in the $\mathrm{Mg}$-Mg pair radial distribution function in amorphous $\mathrm{Mg}_{2} \mathrm{SiO}_{4}$ at $40 \mathrm{GPa}$ relates to existence of two peak in the $\mathrm{Mg}-\mathrm{O}-\mathrm{Mg}$ bond angle distribution in $\mathrm{MgO}_{\mathrm{y}}$ units.

\section{Acknowledgments}

This research is funded by Vietnam National Foundation for Science and Technology Development (NAFOSTED) under grant number 103.05-2018.37.

\section{References}

[1] D. B. Ghosh, B. B. Karki, First principles simulations of the stability and structure of grain boundaries in $\mathrm{Mg}_{2} \mathrm{SiO}_{4}$ forsterite, Phys Chem Minerals 41 (2014), 163-171. https://doi.org/10.1007/s00269-013-0633-1.

[2] O. Adjaoud, G. Steinle-Neumann and Sandro Jahn, $\mathrm{Mg}_{2} \mathrm{SiO}_{4}$ liquid under high pressure from molecular dynamics, Chemical Geology 256 (2008), 185-192. https://doi.org/10.1016/j.chemgeo.2008.06.031.

[3] S. Guan, X. Zhang, Z. P. Liu, Energy landscape and crystal to crystal transition of ternary silicate $\mathrm{Mg}_{2} \mathrm{SiO}_{4}, \mathrm{~J}$. Phys. Chem. C 120 (2016) 25110-25116. https://doi.org/10.1021/acs.jpcc.6b08942

[4] K. Shimoda, Y. Tobu, M. Hatakeyama, T. Nemoto, K. Saito, Structural investigation of Mg local environments in silicate glasses by ultra-high field ${ }^{25} \mathrm{Mg}{ }^{3}$ QMAS NMR spectroscopy. Am Mineral 92 (2007), 695-698. https://doi.org/10.2138/am.2007.2535.

[5] S. Sen, H. Maekawa, G.N Papatheodorou, Short-range structure of invert glasses along the pseudo-binary join $\mathrm{MgSiO}_{3}-\mathrm{Mg}_{2} \mathrm{SiO}_{4}$ : results from ${ }^{29} \mathrm{Si}$ and ${ }^{25} \mathrm{Mg}$ MAS NMR Spectroscopy, J Phys Chem B 113 (2009),15243-15248. https://doi.org/10.1021/jp9079603.

[6] C. J. Benmore, E. Soignard, M. Guthrie, S. A. Amin, J. K. R. Weber, K. McKiernan,M. C. Wilding, J.L. Yarger, High pressure x-ray diffraction measurements on $\mathrm{Mg}_{2} \mathrm{SiO}_{4}$ glass, J. Non-Cryst. Solids 357 (2011), 2632-2636. https://doi.org/10.1016/j.jnoncrysol.2010.12.064.

[7] N. Tomioka, T. Okuchi, A new high-pressure form of $\mathrm{Mg}_{2} \mathrm{SiO}_{4}$ highlighting diffusion less phase transitions of olivine, Sci Rep 7(1) (2017), 17351. https://doi.org/10.1038/s41598-017-17698-Z.

[8] M. C. Wilding, C. J. Benmore, J. A. Tangeman, S. Sampath, Coordination changes in magnesium silicate glasses, Europhys. Lett. 67 (2004), 212-218. https://doi.org/10.1209/epl/i2003-10286-8.

[9] J. D. Kubicki, A. C. Lasaga, Molecular dynamics simulations of pressure and temperature effects on $\mathrm{MgSiO}_{3}$ and $\mathrm{Mg}_{2} \mathrm{SiO}_{4}$ melts and glasses, Phys Chem Miner 17 (1991), 661-673. https://doi.org/10.1007/BF00202236.

[10] J. S. Frank, S. G. Mark, D. Nevins, Structure, thermodynamic and transport properties of liquid $\mathrm{MgSiO}_{3}$ : Comparison of molecular models and laboratory results, Geochimica et Cosmochimica Acta 75 (2011), 1272-1296. https://doi.org/10.1016/j.gca.2010.12.004. 
[11] P. K. Nico, L. Stixrude, B. K. Bijaya, Thermodynamics, structure, dynamics, and freezing of $\mathrm{Mg}_{2} \mathrm{SiO}_{4}$ liquid at high pressure, Geochimica et Cosmochimica Acta 72 (2008), $1427-1441$. https://doi.org/10.1016/j.gca.2007.12.019.

[12] L. T. San, N. V. Hong, T. Iitaka, P. K. Hung, Structural organization, micro-phase separation and polyamorphism of liquid $\mathrm{MgSiO}_{3}$ under compression, Eur. Phys. J. B 89 (2016) 73. https://doi.org/10.1140/epjb/e2016-60740-4.

[13] N. T. Thao, N. T. Trang, T. D. Hinh, L. V. Vinh, Molecular dynamics simualtions of structural and mechanical properties in $\mathrm{MgSiO}_{3}$ glass, Phys. Status Solidi B (2019), 1900215. https://doi.org/10.1002/pssb.201900215.

[14] N. V. Hong, M. T. Lan, P. K. Hung, Structure and dynamics of liquid MgO under high pressure, High Pressure Research 32 (4) (2012), 509-523. https://doi.org/10.1080/08957959.2012.736506. 